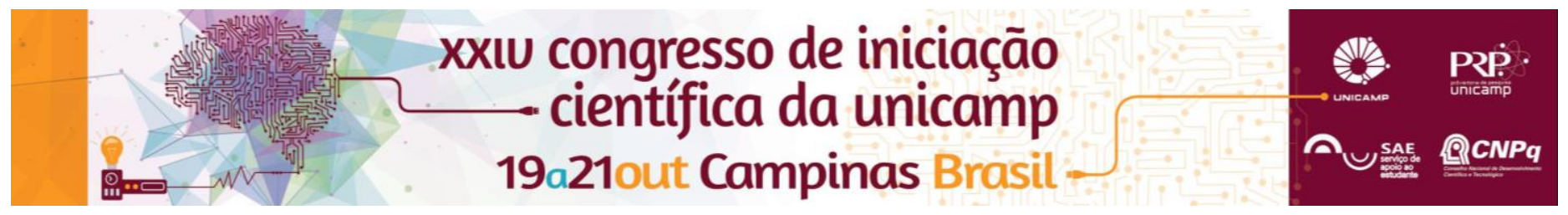

\title{
Uso e ocupação da terra intraurbana no Jardim Rodeira, Campinas (SP)
}

\author{
Ciro Ruiz V. da Silva*, Prof. Dr. Lindon F. Matias
}

\begin{abstract}
Resumo
A pesquisa buscou analisar as mudanças de uso e ocupação da terra na região do Jardim Roseira em Campinas (SP). Em termos gerais, trata-se de um loteamento residencial que começou a ser implantado em 2009 sobre a última gleba existente da antiga Fazenda Roseira gerando uma notável transformação na paisagem do lugar. A própria história da Fazenda Roseira se insere em diversos momentos da história de Campinas, cujas transformações decorrentes da expansão da mancha urbana campineira fez surgir bairros residenciais já na década de 1950 nas primeiras áreas desmembradas da fazenda. As mudanças vistas atualmente remetem, portanto, aos processos e atores de outros momentos do passado. Sendo assim, buscou-se analisar tais transformações recentes e avaliar as consequências deste processo na vida dos moradores locais.
\end{abstract}

Palavras-chave: Geografia urbana, Uso e ocupação da terra, Geotecnologias.

\section{Introdução}

Campinas é uma cidade com uma estrutura urbana bem complexa, fruto de muitas mudanças ao longo de sua história. Esta pesquisa buscou analisar com o auxílio de geotecnologias uma destas transformações que vem ocorrendo desde 2009 na região do Jardim Roseira.

A Fazenda Roseira surgiu no período em que o açúcar começou a ser o principal produto oferecido pelos fazendeiros de Campinas para exportação na segunda metade do século XVIII quando Campinas ainda era Vila. Desde então, a fazenda passou por muitas transformações e em meados do século XX começou a ser desmembrada e a formar diversos bairros como o Jardim Ipaussurama, Jardim Roseira, Vila Perseu Leite de Barros. No entanto, uma gleba ainda resistiu e é a que hoje vem passando por tais transformações.

\section{Resultados e Discussão}

A área de estudos possui cerca de $818.990 \mathrm{~m}^{2}$ e abrange três bairros: Jardim Roseira, Residencial Parque Fazenda e uma pequena parte do Jardim Ipaussurama. O Jardim Roseira e a área do Jardim Ipaussurama já são áreas residenciais consolidadas, elas representam $29 \%$ e $2,5 \%$ respectivamente do total da área de estudos e se encontram na área de estudos justamente para serem base de comparação com a área do residencial ainda em formação. Por sua vez, o Residencial Parque Fazenda abrange $68,5 \%$ da área e representa a última parcela da antiga Fazenda Roseira, a porção ainda em formação desde 2009.

Do ponto de vista urbano, a localização da área de estudos às margens da Avenida John Boyd Dunlop é um fator importante para entender suas particularidades. Resultado de uma forte especulação imobiliária, esta transformação em curso no atual residencial permitiu notar como se deu e como ainda se dá a atuação de diversos "agentes sociais" como os proprietários fundiários, os promotores imobiliários, o Estado e também os grupos sociais excluídos (CORREA, 2000). Os interesses e o embate desses agentes foram relevantes para que a gleba remanescente da antiga fazenda se tornasse um loteamento residencial de fato e para que a antiga sede da Fazenda Roseira se tornasse uma casa de cultura popular (MARTINS, 2011).
No que diz respeito ao uso de geotecnologias, com o software ArcGIS 10.3 (MINAMI, 2000) e a interpretação de imagens de satélite obtidas junto ao software Google Earth foram produzidos dois mapas de uso da terra buscando caracterizar os usos da área antes das mudanças observadas (2005) e também no momento atual (2015/16). As classes de uso da terra adotadas em escala intraurbana foram adaptadas das classes proposto pelo IBGE (2013).

No trabalho de campo realizado em 08 de junho de 2016 na área foi possível observar a realidade atual da região e levantar informações relevantes para o mapeamento. Do mapeamento, foi possível extrair que, em 2005 , $68,5 \%$ da área de estudos (o correspondente à área da antiga gleba e atual residencial) era Vazio Urbano. Em $2015 / 16$, esta classe é de apenas $22,5 \%$, sendo que a maior parte $(68,7 \%)$ são Lotes Desocupados, evidenciando a tendência futura do uso residencial para a área em questão.

\section{Conclusões}

O aumento do número de moradores nessa nova área tenderá a aumentar a demanda por melhores alternativas de transporte, mais opções de lazer e, entre outras questões, também por segurança.

De modo geral, a produção cartográfica das informações históricas levantadas de Campinas contribuíram para entender melhor o que vem ocorrendo atualmente na área de estudos e quais as demandas que estas mudanças levarão ao poder público.

\section{Agradecimentos}

Ao PIBIC/CNPq pelo fomento desta pesquisa.

CORRÊA, R. L. A. O espaço urbano. 4. ed. São Paulo: Ática, 2000. IBGE. Manual Técnico de Uso da Terra. 3. ed. Rio de Janeiro, 2013

MARTINS, Alssandra Ribeiro. Requalificação Urbana: A Fazenda Roseira e

a Comunidade Jongo Dito Ribeiro Campinas/SP. 2011. 123 f. Dissertação

(Mestrado) - Curso de Urbanismo, PUC Campinas, Campinas, 2011.

MINAMI, M. Using ArcMap. ESRI: Redlands, 2000 